\title{
Introduction to the special issue on the political economy of multilateral trade negotiations
}

\author{
Peter Egger • Marcelo Olarreaga
}

Published online: 21 May 2014

(C) Springer Science+Business Media New York 2014

Multilateral trade negotiations (MTNs) are on life support. ${ }^{1}$ The Doha Round of negotiations launched in 2001 has missed most of the targets set in the "July Package" of 2004. If the success of the Trade Facilitation Agreement concluded in Bali in December 2013 gives some hope, it should be reminded that this is a fairly narrow agreement where the necessary funds for its implementation are yet to be found.

It is clear that the system has found its limits and as Richard Baldwin's article in this special issue suggests "it is time to start thinking ahead on global trade governance." The papers in this special issue all help us better understand the causes and consequences of the deadlock in MTNs. The interaction of political economy forces within and across countries is at the heart of the analysis. The papers suggests that the deadlock could be partly explained by a misunderstanding of how these different political economy forces interact with each other, as well as with negotiations in other forums, such as bilateral, regional and plurilateral agreements. A failure by negotiators in the World Trade Organization (WTO) to understand how trade in the 21 st century differs from 20th century trade may have misled them when they defined the negotiating agenda. This may explain why there is so little domestic political support among WTO members for the issues put forward in the 2004 "July Package."

Over the last two decades the political economy literature has made important progress in helping understand the different rationales behind international trade agreements and their impact. The internalization of terms-of-trade effects among large trading partners has been shown to be an important rationale behind trade agreements trying to solve a prisoners' dilemma (Bagwell and Staiger 1999, 2011). These models often allow for domestic politics but tend

\footnotetext{
${ }^{1}$ The Multilateral Trading System, and in particular its Dispute Settlement Body is growing in the number of disputes and its importance for trade policy, perhaps partly due to the lack of successful negotiations.

P. Egger

ETH Zürich, Zürich, Switzerland

e-mail: egger@kof.ethz.ch

M. Olarreaga ( $\square)$

University of Geneva, Geneva, Switzerland

e-mail: marcelo.olarreaga@unige.ch
} 
not to affect the optimal outcome, as the rationale for trade negotiations is driven by terms-of-trade externalities and not domestic politics (Grossman and Helpman 1995).

However, the literature has also suggested rationales in which internal politics are important for trade negotiations. Maggi and Rodríguez-Clare (1998) argue that governments (in small countries) that suffer from credibility problems in their interactions with domestic lobbies could use trade agreements as an external enforcement to tie their hands in the internal political game, and therefore avoid welfare-reducing time-inconsistent decisions. ${ }^{2}$ Bill Ethier has also been advocating for a long time that trade economists need to pay more attention to how international trade agreements change internal politics and less to terms-of-trade externalities. ${ }^{3}$

These two rationales have difficulty explaining why large trading partners engage with small trading partners in trade negotiations. Indeed, the internalization of a small trading partners' terms-of-trade externality, or its inability to credibly commit to a certain policy when facing domestic lobbies, does not in principle create any incentives for large trading partners to sit at the negotiating table with their smaller partners. Size and income asymmetries among negotiating partners are clearly identified in several papers of this special issue as part of the reason why multilateral trade negotiations are stagnating (Baldwin 2014; Evenett 2014; Hoekman 2014). Dealing with these asymmetries in a constructive way is an important challenge for the multilateral trading system in the 21 st century. One issue on which several authors in this special issue agree is that "special and differential treatment" granted to developing countries has had its time, and multilateral trade negotiators need to move forward if the multilateral trading system is to deliver.

Limão (2007) provides an interesting rationale for large trading partners to negotiate with smaller partners: non-economic objectives. The argument is put forward within a preferential trade agreement setup where the pursuit of noneconomic objectives has become quite common over recent years. However, extending Limão's logic to multilateral trade negotiations may help solve the gridlock in multilateral trade negotiations. Social, environmental and international security issues are being negotiated at the regional and bilateral level by large and small trading partners. Is there something for the multilateral system to learn from these experiences at the regional and bilateral level? Baldwin (2014) and Hoekman (2014) suggest that this is the case, and that there may be a lot more to learn from preferential trade agreements than the inclusion of non-economic objectives. There is also a need to learn from other prominent forms of agreements at the bilateral level, such as investment agreements which have become more relevant in a world where global value chains are an important part of the production technology. Complementing these types of bilateral or multilateral agreements with credible domestic reforms should also be an important consideration as suggested by Tobin and Rose-Ackerman (2011). Indeed, if investment agreements are to have an impact on foreign

\footnotetext{
${ }^{2}$ Maggi and Rodríguez-Clare (2007) provide a model where both rationales are integrated.

${ }^{3}$ See for example Ethier (2013).
} 
investment flows they first need to have an impact on domestic legislation and institutions.

\section{Articles in this special issue}

The papers in this special issue provide several interesting avenues on how progress can be achieved at the multilateral level in various areas. The first step before looking forward is to try to understand the causes of the deadlock in multilateral trade negotiations.

In the first paper, Evenett (2014) focuses on how negotiators' self-imposed constraints, domestic politics, and external factors interacted during the early years of the Doha Round to prevent a successful conclusion of the negotiations. The tensions between the negotiating interests of industrialized countries (the North) and their developing country trading partners (the South) is at the heart of his analysis. He follows a graphical approach that allows projecting internal and external factors into a two-dimension graph in which North and South negotiators need to agree on a mutually acceptable market access deal, labelled "the landing zone."

The landing zone is determined by the strategic complementarity over tariff cuts due to South and North's domestic political constraints. The North is willing to provide more market access to the South if the South provides more access to the North. In other words, the North will only accept deals in which there is a sufficiently large degree of market access provided by the South for a given market access concession by the North. The same is true for South negotiators. The market access concessions that satisfy these two ratification constraints simultaneously constitute the landing zone.

Evenett (2014) then analyzes how different internal and external shocks to the Doha negotiations have significantly reduced the size of the landing zone. The loss of Fast Track Authority in the United States, and the need for the European Union to ratify trade deals following the implementation of the Treaty of Lisbon have tightened the North ratification constraint which implies less market access concessions by the North for a given level of liberalization in the South. This clearly reduces the landing zone. He also analyzes how the rapid growth in exports from China and India, as well as tariff overhangs and China's accession to the WTO have all tended to reduce the landing zone of the Doha negotiations.

Interestingly, he also analyzes how constraints imposed by negotiators themselves have tended to reduce the landing zone. The Less Than Full Reciprocity (LTFR) rule, defined in 2008 by the Director-General of the WTO as the "developed world making two third of the contribution and the emerging part of the developing world only one third" may eliminate the landing zone depending on the tightness of the North's ratification constraint. The LTFR rule also suggests that China's accession to the WTO had a stronger impact on the landing zone through its impact on the North's ratification constraint rather than on the South's ratification constraint, putting to rest the argument that it is intra-South dynamics that made the Doha negotiations stumble.

In the second paper, Gradeva and Jaimovich (2014) revisit the question of how the lack of progress in multilateral trade negotiations may affect the spread of regional trade negotiations. Lack of progress at the multilateral level has often been seen as the cause 
of a rapid spread in regionalism as negotiators try to find alternatives to improve the market access of exporting firms through preferential deals. Depending on whether regionalism is then seen as a building or stumbling block for multilateral trade negotiations, we could have a virtuous or vicious circle between trade agreements at the multilateral and regional level. However, unlike existing empirical work on how the lack of progress at the multilateral level explains the spread of regionalism, Gradeva and Jaimovich (2014) find no support for this hypothesis and therefore they leave little room for either a virtuous or vicious circle between multilateral and regional trade agreements.

Their empirical strategy relies on Mansfield and Reinhard (2003) who have shown that the probability of observing a preferential trade agreement between two countries increases with the number of GATT/WTO members in the previous year, or when a multilateral round of trade negotiations is underway, or when a country in the dyad initiates a WTO dispute with a third country in the previous year, or when a country in the dyad loses a WTO dispute.

Gradeva and Jaimovich (2014) extend the dataset in Mansfield and Reinhard (2003) to include the years after the 1994 Marrakech agreement up to 2007. This turns out to be important as the impact of different rounds on the spread of regionalism seems to be quite heterogeneous with early rounds contributing to the spread of regionalism, whereas later rounds do not seem to significantly influence the spread of regionalism. The new dataset used in Gradeva and Jaimovich also considers trade agreements that were not formally notified to the WTO and they distinguish between Free Trade Areas (FTA) and Customs Unions (CUs) on the one side and partial preferential agreements on the other. They also check the robustness of results to considering the European Union members as a single country rather than as individual countries, as in Mansfield and Reinhard (2003). They conclude that results are far from robust to these modifications, especially when considering the years after the Uruguay Round.

Other forces than lack of progress at the multilateral level are driving the spread of regionalism since the Uruguay Round. Part of the reason could be the potential for deeper and broader and more innovative agreements at the bilateral or regional level that correspond better to the needs societies face today.

In the third article of this special issue, van der Marel and Miroudot (2014) explore the reasons behind the shallow commitments in the services sector at the multilateral level relative to the commitments undertaken by the same countries in preferential trade agreements. They first report a significant commitment gap at the multilateral level that seems to be larger for middle income countries. There are also larger gaps in the distribution, transport and business service sectors than in the construction and financial services sector where the commitment gap is significantly smaller. The commitment gap is also larger in modes 1 and 2, which tend to be the more open modes of trade in services, whereas mode 4 , which is the less liberalized mode of trade in services, has the smallest commitment gap. Thus, the gap is larger where it has been easier to liberalize, or more difficult to maintain barriers to trade. This observation suggests that lobbying and domestic politics may not be the only force behind the commitment gap.

The paper then explores the economic and political determinants of the commitment gap in services trade negotiations. Geographic variables such as distance and having a common border play an important role in explaining the commitment gap. Distance tends to reduce the commitment gap, but having a common border also reduces it. Van 
der Marel and Miroudot (2014) explain the difference on the impact of neighboring and non-neighboring countries for a given distance by the reluctance governments may have to provide deep concessions to countries with which the natural obstacles to trade are relatively small. This is because factors of production are easier to move between contiguous countries whereas this is less the case when countries are further away. Hence, the advantage of going deeper in an RTA starts with countries which are close but not share any border. When it comes to neighbors, preferential trade negotiations in services are seen as a substitute to geography and not as a complement.

Among economic variables it is the endowments of mid-skilled labor that plays the most important role in explaining the commitment gap. The larger the mid-skilled labor endowment, the smaller the commitment gap. This suggests that countries with a relatively large endowment of mid-skilled labor tend to make relatively weaker commitments at the regional level. On the institutional side, democracies seem to have smaller commitment gaps, making them again more hesitant to engage in deep preferential trade liberalization in services. The results are usually robust across different services sectors and modes of trade.

Interestingly, the commitment gap is higher for North-North agreements, which suggests that among this group of countries, when they are not too far apart (but not neighbors) and are not largely endowed in mid-skilled labor, trade negotiations are easier. This suggests that a plurilateral initiative among these countries such as the Trade in Services Agreement (TISA) currently being envisaged is much more likely to succeed in liberalizing trade in services than multilateral negotiations in the WTO as currently underway.

In the fourth paper, Hoekman (2014) explores how preferential or rather megaregional trade agreements such as TISA, the Trans-Pacific Partnership (TPP), and the Transatlantic Trade and Investment Partnership (TTIP) will affect the smaller excluded countries, which are stuck in the slowly moving Doha Round. He suggests several avenues that these smaller and excluded countries could follow in response to the negotiation of preferential trade agreements by their larger trading partners. Addressing this issue is crucial if we want the world trading system to fill the perceived "development deficit" created by the Uruguay Round and that the Doha Development Agenda was meant to correct.

Hoekman (2014) first highlights that our existing economic tools that address the impact of preferential trade agreements on excluded countries based on the idea of trade diversion are outdated, partly because most of the countries engaged in the megaregional trade agreements tend to have very small Most-Favoured-Nation tariffs, but also because a significant amount of what is being discussed in these agreements are regulatory changes which are mostly non-discriminatory. On the contrary, depending on the type of regulation and on the capacity of excluded countries to adapt to the changes in regulation that will result from the mega-regional and plurilateral services trade agreements, they may end up experiencing an improvement in their market access to countries within mega-regional or plurilateral agreements. As Hoekman points out this will likely require an investment in learning and understanding by excluded countries of what gets negotiated in mega-regional and plurilateral trade agreements. It may also require that excluded countries be ready to bring within the multilateral trading system this learning and experience that is taking place outside the WTO by their larger trading partners. 
To help this learning and absorption of new technology for cooperation on economic policies within the WTO, the paper proposes several avenues. The easiest to implement, at least from a technical point of view, is to change Article X.9 of the WTO Agreement that establishes that adding a plurilateral agreement in the WTO can be done "exclusively by consensus." The language is clearly too strong if the plurilateral option is to be seriously considered within the WTO. In the same spirit as Article XXIV, Hoekman (2014) suggests that the language should be changed to allow plurilateral agreements when the signatories of the agreement represent a sufficiently large share of world trade or of the WTO membership. Such a reform is technically very cheap, as it only requires changing the text of the WTO agreement, but it may be very difficult and politically very costly to achieve as emerging economies are entrenched in the LTFR rule.

To help the potential for learning about regulatory reform from plurilaterals and mega-regionals, Hoekman suggests the creation of "knowledge platforms" in the WTO, designed to discuss the impacts and complementarities among different kinds of trade-related policies. Different types of regulatory policies tend to be negotiated in different WTO forums, and complementarities are rarely explored. This clearly ignores that the recent rapid growth in trade through global value chains requires a better understanding of the entire set of regulatory policies to identify bottlenecks. Much like in the O-Ring theory of development, the trading system today is as efficient as its weakest links. ${ }^{4}$ Thus, to make trade negotiations relevant for firms engaged in global trade, a comprehensive approach is needed, and much can be learned from what's happening in plurilateral and mega-regional trade agreements. An interesting idea to move towards a more comprehensive approach is the proposal to organize "supply chain councils" on a selected number of specific production networks to help identify the most binding regulatory policy constraints and to prioritize these for joint action. This should definitely bring more interest by the private sector on what's being negotiated and discussed in the WTO and help increase Evenett's (2014) landing zone.

In the final paper of this special issue, Baldwin (2014) argues that the WTO is becoming irrelevant because its agreements and institutional functioning have ignored the fundamental shift in the mechanics of world trade towards the unprecedented increase in cross-border flow of goods, investment, services, know-how and people associated with international production networks. The time has come for WTO 2.0.

WTO 2.0 should acknowledge that the rise in global value chains has significantly changed the political economy of trade negotiations. In a stylized world where the North owns the technology and the South is abundant in cheap labor, the impact of increased trade on different agent's real income is very different from the one of traditional trade, where producers are located in one country and consumers in another. As global value chains emerge, firms in the North will stop producing domestically and start combining cheaper labor in the South with their Northern technology. Firms in the North will be better off and

\footnotetext{
${ }^{4}$ See Kremer (1993).
} 
firms in the South will suffer from tougher competition. This tougher competition will benefit consumers both in the North and South. Workers in the North will oppose the shift towards global value chains but workers in the South will embrace as North firms relocate in the South. To successfully conclude trade agreements there is a need to understand the changes in political economy forces behind any deal.

The emergence of global value chains puts new governance demands on the world trading system. The first one is that firms need to be able to produce abroad and this requires better property assurances of tangible and intangible assets. This suggests that in a world with international production we need a multilateral system that helps solve holdup problems rather than prisoners' dilemma problems as the one we referred to earlier when discussing terms-oftrade externalities. Indeed, WTO 2.0 needs to help the South to avoid the temptation to expropriate the North from its superior technology once it has invested in the South. The existence of holdup equilibrium, and the absence of adequate governance to solve them, probably explains why some regions, such as South America and Sub-Saharan Africa are not participating in international production networks.

The second demand has to do with the need to coordinate across internationally dispersed regions to ensure that there are no disruptions associated with intermediate inputs crossing borders in order to produce final goods, which in turn will probably also cross borders. However, the need for coordinating is less universal than in a world without production networks. The need for a production network to operate smoothly is more local and therefore the need for universal membership in WTO 2.0 is weaker. However, as firms operate in different production networks, there is a case to be made for multilateralizing the governance of production networks under a common set of rules.

Finally, Baldwin (2014) convincingly argues that in this new world with international production the need to grant special and differential treatment to developing countries vanishes. In a world where trade agreements' role is to solve terms-of-trade externalities, trade barriers imposed by an importing country improves its terms-of-trade and deteriorates the terms-of-trade of other countries. If a developing country is provided an exemption from full reciprocity through special and differential treatment, it can be argued that this helps the developing country. Thus, special and differential treatment had some development logic. However, in a world with international production networks, exempting a country from the disciplines that are necessary to join the supplychain will only hurt countries benefiting from this exemption. Thus, there is no room for special and differential treatment in WTO 2.0.

The aim of this special issue was never to try to solve the deadlock in multilateral trade negotiations. However, the papers offer a very refreshing view of the political economy literature on multilateral trade negotiations and its relationship with bilateral and regional trade negotiations. The papers probably raise more questions than they answer, and we expect the literature to follow more deeply some of the new ideas put forward in this special issue. Perhaps, more importantly, by providing a refreshing look into the political economy issues that cause the slowdown in multilateral trade negotiations and by 
suggesting promising avenues that could help solve this deadlock, the five papers in this special issue can start paving the road for a more efficient multilateral trading system.

\section{References}

Bagwell, K., \& Staiger, R. W. (1999). An economic theory of GATT. American Economic Review, 89(1), 215248.

Bagwell, K., \& Staiger, R. W. (2011). What do trade negotiators negotiate about? Empirical evidence from the world trade organization. American Economic Review, 101(4), 1238-1273.

Baldwin, R. (2014). WTO 2.0: governance of 21st century trade. Review of International Organizations, 9(2). doi:10.1007/s11558-014-9186-4.

Ethier, B. (2013). The trade agreement embarrassment. Penn Institute for Economic Research Working Paper \#13-049.

Evenett, S. (2014). The Doha round impasse: a graphical account. Review of International Organizations, 9(2). doi:10.1007/s11558-014-9195-3.

Gradeva, K., \& Jaimovich, D. (2014). Multilateral determinants of regionalism revisited. Review of International Organizations, 9(2) doi:10.1007/s11558-014-9193-5.

Grossman, G. M., \& Helpman, E. (1995). Trade wars and trade talks. Journal of Political Economy, 103(4), 675-708.

Hoekman, B. (2014). Sustaining multilateral trade cooperation in a multi-polar world economy. Review of International Organizations, 9(2). doi:10.1007/s11558-014-9187-3.

Kremer, M. (1993). The O-ring theory of economic development. Quarterly Journal of Economics, 108(3), 551-575.

Limão, N. (2007). Are preferential trade agreements with non-trade objectives a stumbling block for multilateral liberalization? Review of Economic Studies, 74(3), 821-855.

Maggi, G., \& Rodríguez-Clare, A. (1998). The value of trade agreements in the presence of political pressures. Journal of Political Economy, 106(3), 574-601.

Maggi, G., \& Rodríguez-Clare, A. (2007). A political-economy theory of trade agreements. American Economic Review, 97(4), 1374-1406.

Mansfield, E., \& Reinhard, E. (2003). Multilateral determinants of regionalism: the effects of GATT/WTO on the formation of preferential trade agreements. International Organization, 57(4), 829-862.

Tobin, J., \& Rose-Ackerman, S. (2011). When BITs have some bite: the political-economic environment for bilateral investment treaties. Review of International Organizations, 6, 1-32.

Van der Marel, E., \& Miroudot, S. (2014). The economics and political economy of going beyond the GATS. Review of International Organizations, 9(2). doi:10.1007/s11558-014-9189-1. 